\title{
Use of monoclonal antibodies for the histopathological diagnosis of human malignancy
}

\author{
KC GATTER, ${ }^{*} Z$ ABDULAZIZ, ${ }^{*}$ P BEVERLEY $†$ JRF CORVALAN, IC FORD, $\ddagger$ EB LANE, $\S$ \\ $\mathrm{M}$ MOTA, ${ }^{*} \mathrm{JRG}^{\mathrm{N}} \mathrm{NASH},{ }^{*} \mathrm{~K}$ PULFORD, ${ }^{*}$ H STEIN, \|J TAYLOR-PAPADIMITRIOU, $\S$ \\ C WOODHOUSE, $\ddagger$ DY MASON*
}

From the * Nuffield Department of Pathology, University of Oxford, John Radcliffe Hospital, Oxford, the $\dagger$ ICRF Human Tumour Immunology Unit, University College Hospital, London, the $\ddagger$ Surgical Immunology Unit, Queen Elizabeth Hospital, Birmingham, the §Imperial Cancer Research Fund, Lincoln's Inn Fields, London, the \|| Institute of Pathology, Christian Albrechts University, Kiel, West Germany, and the II Lilly Research Centre, Windlesham, Surrey

SUMMARY This paper describes the use of a panel of seven monoclonal antibodies (selected so as to include reagents reactive with both epithelial and lymphoid cells) for distinguishing between anaplastic carcinoma and high grade lymphoma. Details are given of the immunohistological reactions of these antibodies against a wide range of both normal and malignant tissues and of a number of practical instances in which use of the antibody panel enabled a diagnosis to be made when routine histological examination had been inconclusive.

For almost a century routine histopathological diagnosis has been based upon the examination of haematoxylin and eosin stained paraffin-embedded tissue sections, supplemented on occasion by the use of special stains such as the periodic acid-Schiff (PAS) reaction. Although the majority of tissues received in routine histopathology laboratories can be reliably diagnosed in this way, there are a number of cases in which a firm diagnosis cannot be made on morphological grounds alone.

One way to solve such diagnostic problems is to use immunohistological staining techniques. However until now this approach, although of genuine diagnostic value in occasional cases, has been limited in its scope by the relatively small number of tissue antigens which can be detected with currently available antisera. In consequence immunohistological staining techniques have remained a minority interest among pathologists, and play an insignificant role in the context of routine histopathological diagnosis.

The range of antigenic constituents which can be detected by immunohistological techniques in human

Accepted for publication 29 March 1982 tissue has recently been dramatically expanded by the advent of monoclonal antibodies. Some of the human tissue antigens recognised by recently produced monoclonal antibodies have already been studied (albeit on a limited scale) using conventional antisera. Other antibodies-for example, those identifying different $T$ lymphocyte subclasses-represent valuable new cell markers which cannot be recognised with conventional antisera.

This increase in the number of detectable human tissue antigens suggests that immunohistological analysis of surgical biopsies using monoclonal antibodies may now come to play a greater role in the context of routine diagnosis. In the present paper we describe the use of a panel of monoclonal antibodies as probes for specific antigens (selected so as to include reagents reactive with both epithelial and lymphoid cells) to enable cases of anaplastic carcinoma to be distinguished from samples of high grade lymphoma. Details are given of practical instances in which use of the monoclonal antibody panel was of direct clinical relevance. These results suggest that immunohistological labelling with panels of monoclonal antibodies will become of increasing importance in the future in routine diagnostic histopathology. 
Material and methods

\section{PREPARATION OF TISSUE SAMPLES}

Surgical biopsies were received fresh from the operating theatre. A representative portion was removed for immunohistological examination and the remainder was processed in the conventional manner by formalin fixation and paraffin embedding.

The portion of unfixed tissue was immediately frozen in liquid nitrogen and stored in a liquid nitrogen refrigerator. Cryostat sections $(5-10 \mu \mathrm{m}$ in thickness) were collected on gelatin-coated glass slides, thoroughly dried (by dessication for 4-18 $\mathrm{h}$ in the vacuum chamber of a freeze drying apparatus) and fixed in acetone for $10 \mathrm{~min}$ at room temperature. Sections were then air-dried and either stained immediately by the immunoperoxidase procedure (see below) or else wrapped in aluminium foil and stored at $-20^{\circ} \mathrm{C}$.

\section{MONOCLONAL ANTIBODIES}

Details of the origin of the monoclonal antibodies used in this study are given in Table 1. The specificities of their reactions are discussed in the text.

\section{IMMUNOPEROXIDASE REAGENTS}

Sheep antiserum against mouse immunoglobulin was raised by a conventional immunisation schedule. Peroxidase-conjugated rabbit antimouse immunoglobulin was obtained from Dako Immunoglobulins a/s. Soluble PAP complexes of horseradish peroxidase and monoclonal mouse antiperoxidase were prepared as described previously ${ }^{6}$ by adding horseradish peroxidase (RZ value 3.0-Sigma Chemical Co) at $0.05 \mathrm{mg} / \mathrm{ml}$ to culture supernatant from the antiperoxidase-secreting cell line $P 6 / 38$.

Table 1 Details of monoclonal antibodies used for the immunohistological analysis of human tissues

\begin{tabular}{llll}
\hline Antibody & Reference & Antigen & $\begin{array}{l}\text { Also referred to } \\
\text { in text as: }\end{array}$ \\
\hline $\begin{array}{l}\text { CR3/43 } \\
\text { 2D1 }\end{array}$ & $\begin{array}{l}\text { Naiem M, et al } \\
\text { Beverley P }^{2}\end{array}$ & $\begin{array}{l}\text { HLA-DR } \\
\text { HLE-1 } \\
\text { leucocyte } \\
\text { associated } \\
\text { antigen }\end{array}$ & $\begin{array}{l}\text { HLA-DR } \\
\text { 2D1 }\end{array}$ \\
MFG-1* & $\begin{array}{l}\text { Taylor- } \\
\text { Papadimitriou J, } \\
\text { MFG-2 al }\end{array}$ & $\begin{array}{l}\text { Human milk } \\
\text { fat globule } \\
\text { membrane }\end{array}$ & MFG \\
LE61 & $\begin{array}{l}\text { Arklie J, et al }{ }^{4} \\
\text { Lane EB }\end{array}$ & $\begin{array}{l}\text { Simple epithelium } \\
\text { antigen on } \\
\text { cytokeratin } \\
\text { filaments } \\
\text { Carcinoembryonic CEA } \\
\text { antigen }\end{array}$ & SEA \\
11.285 .14 & $\begin{array}{l}\text { Corvalan JRF, } \\
\text { Woodhouse CS } \\
\text { (unpublished) } \\
\text { Pulford K } \\
\text { (unpublished) }\end{array}$ & $\begin{array}{l}\text { Keratin associated Keratin } \\
\text { component }\end{array}$ \\
\hline K92 &
\end{tabular}

${ }^{*}$ Referred to in original reference as 1.10.F3 (MFG-1) and 14.A.3 (MFG-2).
PAP complexes prepared in this way were stored for at least $18 \mathrm{~h}$ at $4^{\circ} \mathrm{C}$ before use. Diaminobenzidine tetrahydrochloride was obtained from the Sigma Chemical Co. Tris-buffered saline (TBS) was prepared by adding a tenth volume of $0.5 \mathrm{M}$ Tris $\mathrm{HCl}$ buffer ( $\mathrm{pH} 7 \cdot 6)$ to $0.5 M$ saline.

\section{IMMUNOPEROXIDASE STAINING}

Cryostat sections were stained either by an indirect two-stage immunoperoxidase procedure or by a PAP technique. The initial stage in both procedures involved the application of monoclonal antibodies to dry cryostat sections, followed by incubation for 30 min in a covered chamber. The optimal dilution for each antibody was established by titration. Antibodies obtained as culture supernatants were usually used undiluted. Monoclonal antibodies obtained as ascitic fluid required dilution by a variable factor (at least $1 / 100$ ) for use.

After incubation with monoclonal antibodies the sections were washed in TBS. When staining by the indirect immunoperoxidase technique, sections were incubated for a further $30 \mathrm{~min}$ with peroxidaseconjugated antimouse immunoglobulin. This reagent was diluted $1 / 50$ in TBS to which normal human serum (at a final dilution of $1 / 25$ ) was added in order to block cross-reactivity against human immuno- 8 globulin. For PAP staining sections were incubated with sheep antimouse Ig antiserum (diluted 1/25) foro $30 \mathrm{~min}$ and then washed in TBS. Monoclonal PAP? was then applied for a further 30 min before washing again in TBS. Development of the peroxidase reaction was performed by incubating sections with diaminobenzidine $(0.6 \mathrm{mg} / \mathrm{ml})$ and hydrogen peroxide $(0.01 \%)$ for $5-10 \mathrm{~min}$ at room temperature. Sections were then washed in tap water, counterstained with haematoxylin and mounted for microscopical examination.

In addition to labelling tissues with the antibodies detailed in Table 1, all lymphoid tissue samples were analysed with an additional monoclonal antibody panel (including antibodies reactive with $\mathrm{B}$ cells, $\mathrm{T}$ cells and immunoglobulin isotypes) in order to classify them immunologically. These results will be published elsewhere.

\section{Results}

\section{NORMAL TISSUES}

The immunohistological reaction patterns on normal tissues of some of the antibodies listed in Table 1 have already been described in previous reports. ${ }^{3-5}$ However these analyses were performed by different groups of investigators, using techniques which varied considerably in terms of tissue preparation and labelling procedures. For example, the tissue 
distribution of the MFG antigen was determined using immunoperoxidase staining of sections of paraffin-embedded formalin-fixed tissue ${ }^{4}$ while the cytokeratin determinant was detected by indirect immunofluorescence on dried, fresh unfixed cryostat sections. ${ }^{5}$ It was therefore considered necessary to analyse the reaction patterns of these antibodies on tissue sections which had all been prepared in the same way and stained by the same technique. All the observations recorded here refer to acetone-fixed cryostat sections stained by the immunoperoxidase technique, as described under Methods. The range of normal tissues examined was chosen so as to cover the spectrum of tissues from which epithelial and lymphoid malignancies commonly arise. The immunohistological labelling patterns obtained are given in Table 2.

\section{Leucocyte-associated antigen (antibody 2DI) and} $H L A-D R$

Epithelial cells in all samples were negative for the leucocyte-associated antigen as recognised by $2 \mathrm{D} 1$. HLA-DR, as detected by CR3/43, showed a variety of staining patterns in that the epithelium in some tissues was consistently negative (thyroid, prostate) or consistently positive (bile ducts) whilst in other tissues (breast and gut) the reactions varied from specimen to specimen (Fig. 1).

White cells reacting positively for antileucocyteassociated antigen were found in varying proportion in all samples examined. The majority of positive cells had the rounded morphology characteristic of lymphoid cells. In addition, however, elongated cells with a variety of morphological outlines, often resembling fibroblasts were seen in most samples. The anti-HLA-DR antibodies also stained numerous non-epithelial cells in all samples tested. These also showed a range of morphological appearances, although elongated cells were more frequently seen than in the samples stained for the leucocyteassociated antigen. Many of these cells had the appearance of "dendritic cells" 78 (Fig. 2).

Endothelial cells in capillaries frequently stained for HLA-DR (Fig. 1b).

\section{Milk fat globule (MFG) antigens}

The staining patterns for determinants recognised by the two monoclonal antibodies MFG-1 and MFG-2 were qualitatively similar. Both antibodies characteristically bound to the luminal surface of a wide variety of internal epithelial cells (Fig. 3) with the exception of hepatocytes and prostatic epithelia. Some reaction was observed with scattered surface cells in the tonsilar crypt epithelium (not, however, with the same cells as recognised by LE61-see below), but there was no other reaction with stratified squamous epithelium. The observed reactions were similar to those previously reported,${ }^{4}$ although the different fixation technique used here appears to have extended the range of reactive tissues.

Table 2 Reaction of normal epithelial and lymphoid tissue with the panel of monoclonal antibodies

\begin{tabular}{|c|c|c|c|c|c|c|}
\hline \multirow[t]{2}{*}{ Tissue } & \multicolumn{6}{|l|}{ Antigens } \\
\hline & $\begin{array}{l}H L A-D R \div \\
\left(\left(R 3 / 43^{*}\right)\right.\end{array}$ & $\begin{array}{l}\text { Leucocyte associ- } \\
\text { ated antigen } \\
\left(2 D I^{*} \div\right)\end{array}$ & $\begin{array}{l}\text { Milk fat } \\
\text { globule } \\
\left(M F G I \& 2^{*}\right)\end{array}$ & $\begin{array}{l}\text { SEA cytokeratin } \\
\text { filaments } \\
\left(L E 6 I^{*}\right)\end{array}$ & $\begin{array}{l}C E A \\
\left(I I .285 .14^{*}\right)\end{array}$ & $\begin{array}{l}\text { Keratin } \\
\left(K 92^{*}\right)\end{array}$ \\
\hline Skin & - & - & - & - & - & + \\
\hline Brain (cortex) & - & - & - & - & - & - \\
\hline Brcast & $-1+$ & - & + & + & - & Patchy \\
\hline Lung & - & - & + & + & - & - \\
\hline Stomach & $+1-$ & - & $+\div$ & + & + & - \\
\hline Colon & $-1+$ & - & $+\div$ & + & + & - \\
\hline Liver & - & - & - & + & - & - \\
\hline Bile duct & + & - & + & + & - & - \\
\hline Pancreas (exocrine) & - & - & + & + & - & - \\
\hline Kiulney $\{$ Glomeruli & + & - & - & - & - & - \\
\hline Kidney Tubules & $+1-$ & - & + & + & - & - \\
\hline Prostate & - & - & - & + & - & - \\
\hline Testis & - & - & - & - & - & - \\
\hline Thyroid & - & - & + & + & - & - \\
\hline Tonsil (lymphoid) & + & + & - & - & - & - \\
\hline Tonsil (epithelium) & - & - & + & + & + & - \\
\hline Lymph node & + & + & - & - & - & - \\
\hline
\end{tabular}




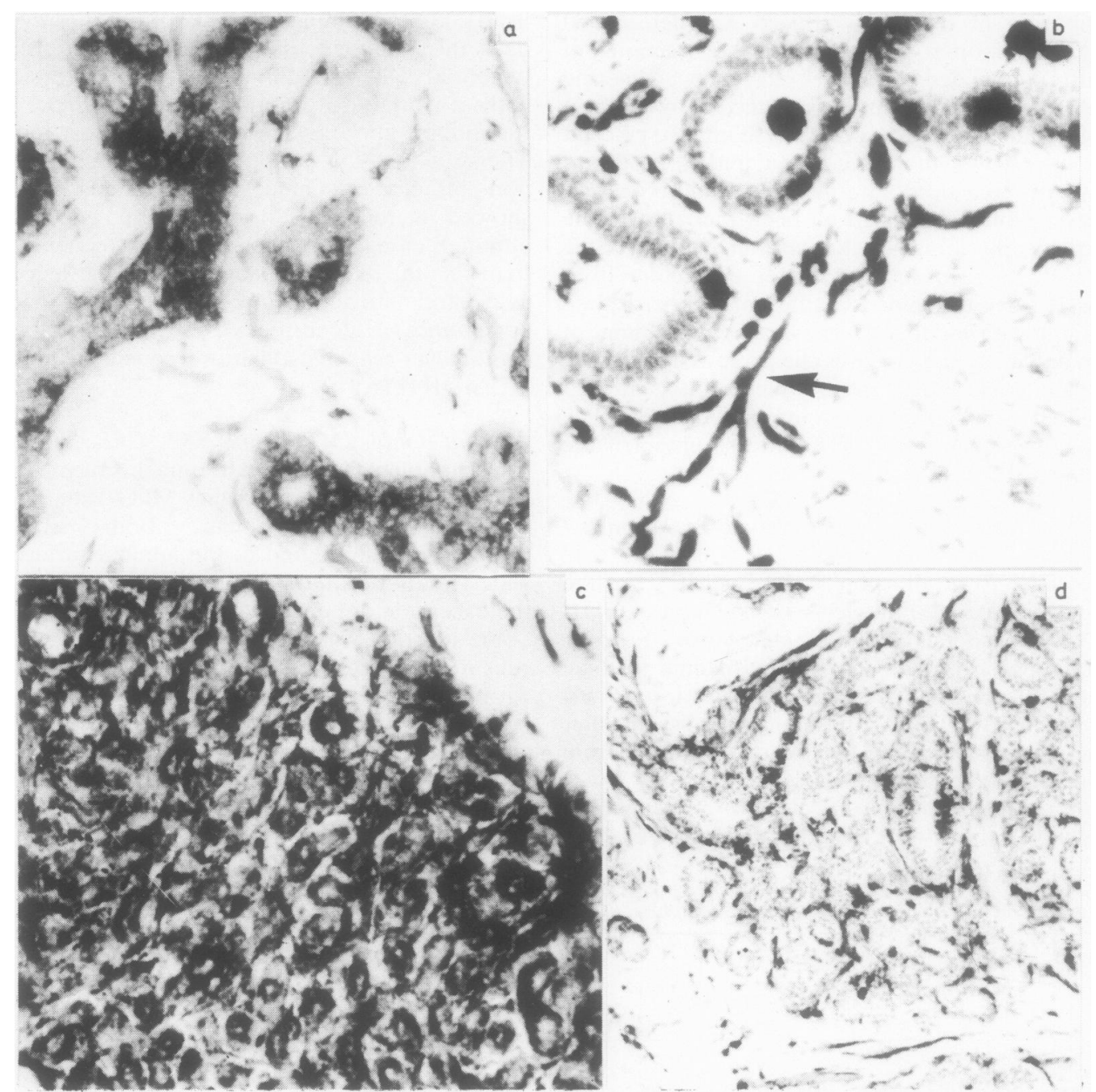

Fig. 1 Normal breast tissue (two different cases) showing ducts which are (a) positive, and (b) negative for $H L A-D R$. Note in (b) the staining of capillaries (arrow) for HLA-DR (both $\times 400)$. In benign fibrocystic disease of the breast it is also possible to find samples which are either (c) positive, or (d) negative for HLA-DR (both $\times 250)$

Simple epithelium antigen (SEA) of cytokeratins (antibody LE61)

In spite of their diverse antigenic origins, ${ }^{45}$ the MFG antibodies described above and this LE61 antibody gave nearly identical tissue staining patterns. LE61 bound to cells of nearly all simple epithelia tested (Fig. 3), but did not react with the cell type characteristic of stratified squamous epithelia, keratinising or non-keratinising. Solitary positive cells were sometimes seen in some squamous $\widetilde{\sigma}$ tissues-for example, tonsilar crypt epithelium-but N this cell type was not identifiable. These observations N్ agree with the distribution of LE61-recognised simple 0 epithelium antigen of cytokeratin filaments seen previously $^{5}$ (EB Lane, unpublished observations 1980) in unfixed frozen sections. The SEA $\stackrel{\oplus}{\rightarrow}$ cytokeratin staining within individual cells however 0 was quite distinct from that of the MFG staining, 


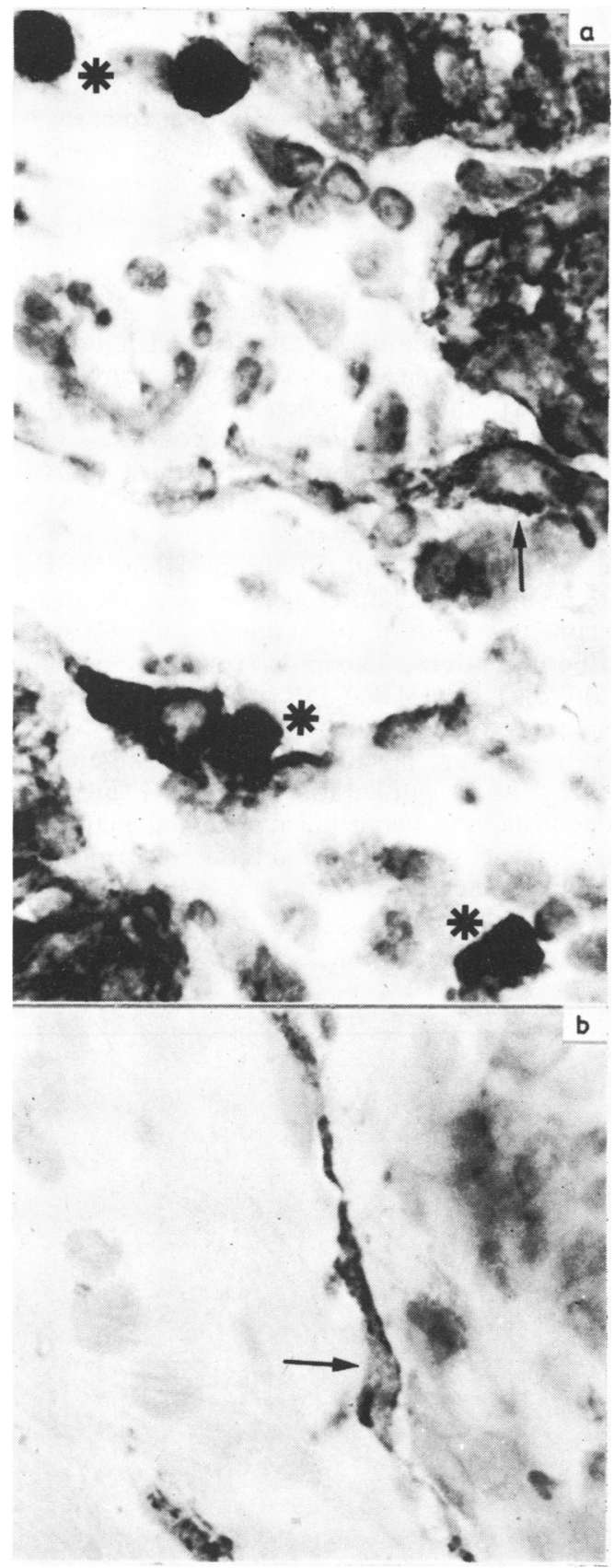

Fig. $2 H L A-D R$ positive cells with the appearance of "dendritic cells" (arrowed) seen in (a) stomach, and (b) normal breast. Myeloid cells with endogenous peroxidase are indicated by $\%$ in (a). Note that the gastric mucosal cells (upper right) are also $H L A-D R$ positive $($ both $\times 900)$

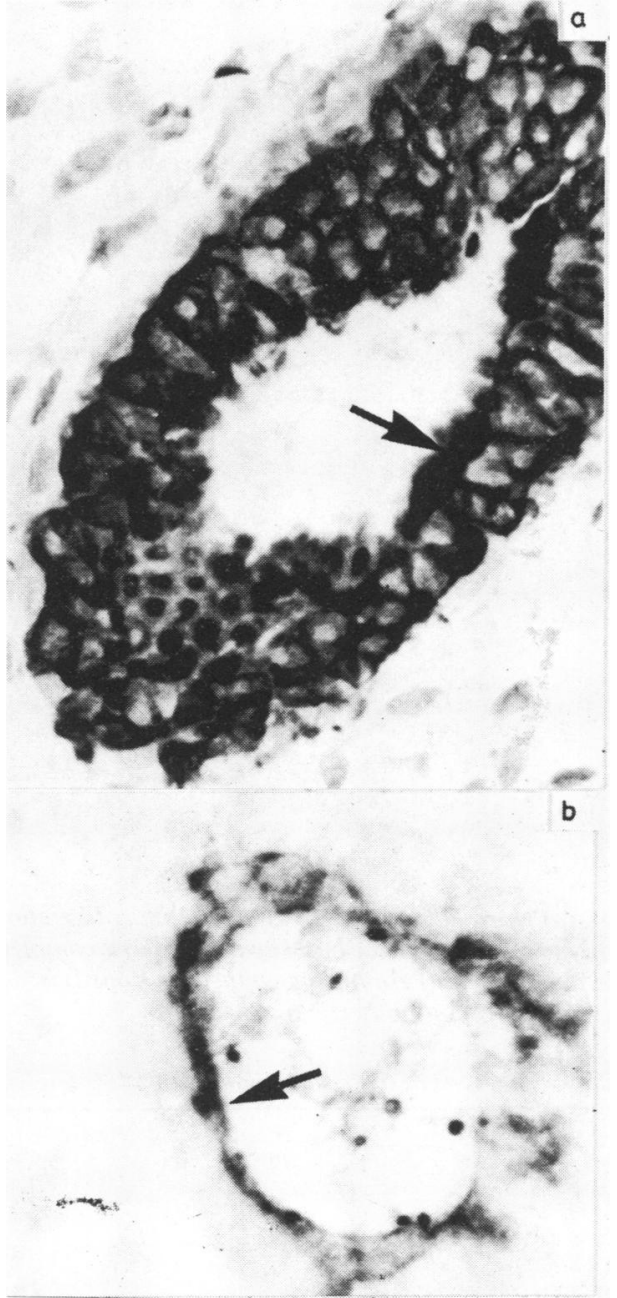

Fig. 3 Normal mammary ducts illustrating (a) the evenly distributed staining of epithelial cells (arrow) for SEA cytokeratin filaments, contrasting with (b) the restricted periluminal staining (arrow) of human milk fat globule antibody $($ both $\times 900)$

since the cytokeratins are present as filaments throughout the cytoplasm and not just at the luminal membrane of the cell.

Carcinoembryonic antigen (CEA)

As determined by the binding of monoclonal antibody 11.285 .14 , this antigen was present in gastrointestinal epithelium (colon and stomach) but absent from other glandular epithelia. Interestingly, superficial non-keratinising crypt epithelium in human tonsil was strongly labelled for this antigen. 


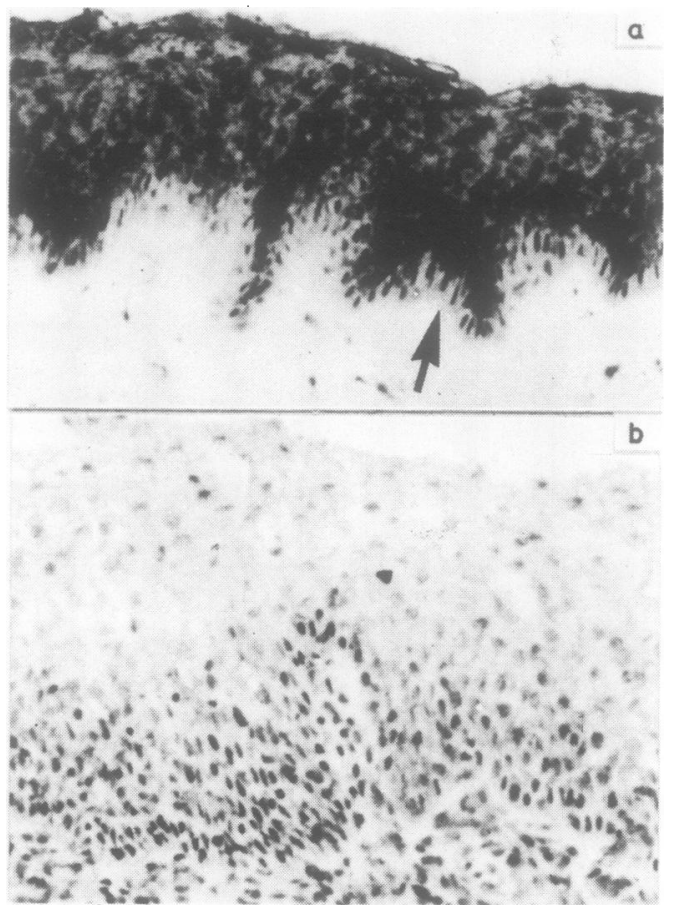

Fig. 4 (a) Normal human skin labelled with antikeratin antibody K92. Note that the basal layer (arrow) is completely unlabelled. (b) Non-keratinising epithelium (tonsil) is negative with this antibody (both $\times 250$ )
Keratin (antibody K92)

The keratin antigen recognised by monoclonal 은 antibody K92 was detectable in cutaneous epithelium (Fig. 4) and also on a minority of mammary duct epithelial cells. Non-keratinising squamous epithelium however was negative (Fig. 4) as were all other tissue samples.

\section{CARCINOMAS}

Details are given in Table 3 of the carcinoma samples $\overrightarrow{0}$ analysed by immunohistological staining. The pattern of antigenic expression in these carcinomata $\vec{\omega}$ resembled that of their normal epithelial counterparts, in that staining for leucocyte-associated ? antigen was consistently negative whilst HLA-DR o showed a variable pattern of staining. This was best $\vec{\exists}$ seen in 11 ductal carcinomas of the breast in which nine were negative and two positive (Fig. 5). There were no histological differences between the cases to explain this pattern of staining with HLA-DR. Furthermore in one carcinoma (papillary carcinoma of thyroid) both HLA-DR positive and negative areas existed side by side (Fig. 5).

All cases were positive for at least one epithelial antigen, SEA cytokeratin and MFG membrane antigen staining being positive in the majority of $\vec{\varphi}$ cases, whereas CEA and keratin were much les frequently detectable.

Table 3 Reactions of malignant tissues with the panel of monoclonal antibodies

\begin{tabular}{|c|c|c|c|c|c|c|c|}
\hline & \multirow{2}{*}{$\begin{array}{l}\text { No of } \\
\text { cases }\end{array}$} & \multicolumn{6}{|l|}{ Antigens } \\
\hline & & $H L A-D R$ & $\begin{array}{l}2 D I \\
\text { (leucocyte- } \\
\text { associated) }\end{array}$ & $\begin{array}{l}\text { MFG } \\
\text { (milk fat } \\
\text { globule) }\end{array}$ & $\begin{array}{l}\text { SEA } \\
\text { (cytokeratin } \\
\text { filaments) }\end{array}$ & $C E A$ & Keratin \\
\hline \multicolumn{8}{|l|}{$\begin{array}{l}\text { CARCINOMA } \\
\text { Squamous cell carcinoma } \\
\text { of skin (lymph node }\end{array}$} \\
\hline metastasis) & 1 & - & - & + & - & Patchy & + \\
\hline $\begin{array}{l}\text { Renal adenocarcinoma } \\
\text { Adenocarcinoma of ovary }\end{array}$ & 1 & + & - & + & + & - & - \\
\hline (omental deposit) & 1 & + & - & + & + & - & - \\
\hline $\begin{array}{l}\text { Adenocarcinoma of ovary } \\
\text { Squamous cell carcinoma } \\
\text { (poorly differentiated) }\end{array}$ & $i$ & + & - & + & + & - & - \\
\hline of lung & 1 & - & - & - & + & - & - \\
\hline Adenocarcinoma of endometrium & 1 & - & - & + & + & - & - \\
\hline $\begin{array}{l}\text { Adenocarcinoma of stomach } \\
\text { Adenocarcinoma of breast }\end{array}$ & 1 & $-\cdot$ & - & + & + & + & - \\
\hline $\begin{array}{l}\text { (lymph node metastasis) } \\
\text { Ductal adenocarcinoma }\end{array}$ & 1 & - & - & + & + & + & Patchy \\
\hline of breast & 11 & $-1+$ & - & + & + & $+1-$ & Patchy \\
\hline $\begin{array}{l}\text { Adenocarcinoma of colon } \\
\text { Embryonal carcinoma }\end{array}$ & 2 & + & - & + & + & + & \\
\hline (retroperitoneal origin) & 1 & - & - & - & + & - & - \\
\hline $\begin{array}{l}\text { Papillary carcinoma of thyroid } \\
L Y M P H O M A\end{array}$ & 1 & Patchy & - & + & + & - & - \\
\hline B cell lymphomas & 22 & + & + & - & - & - & - \\
\hline
\end{tabular}




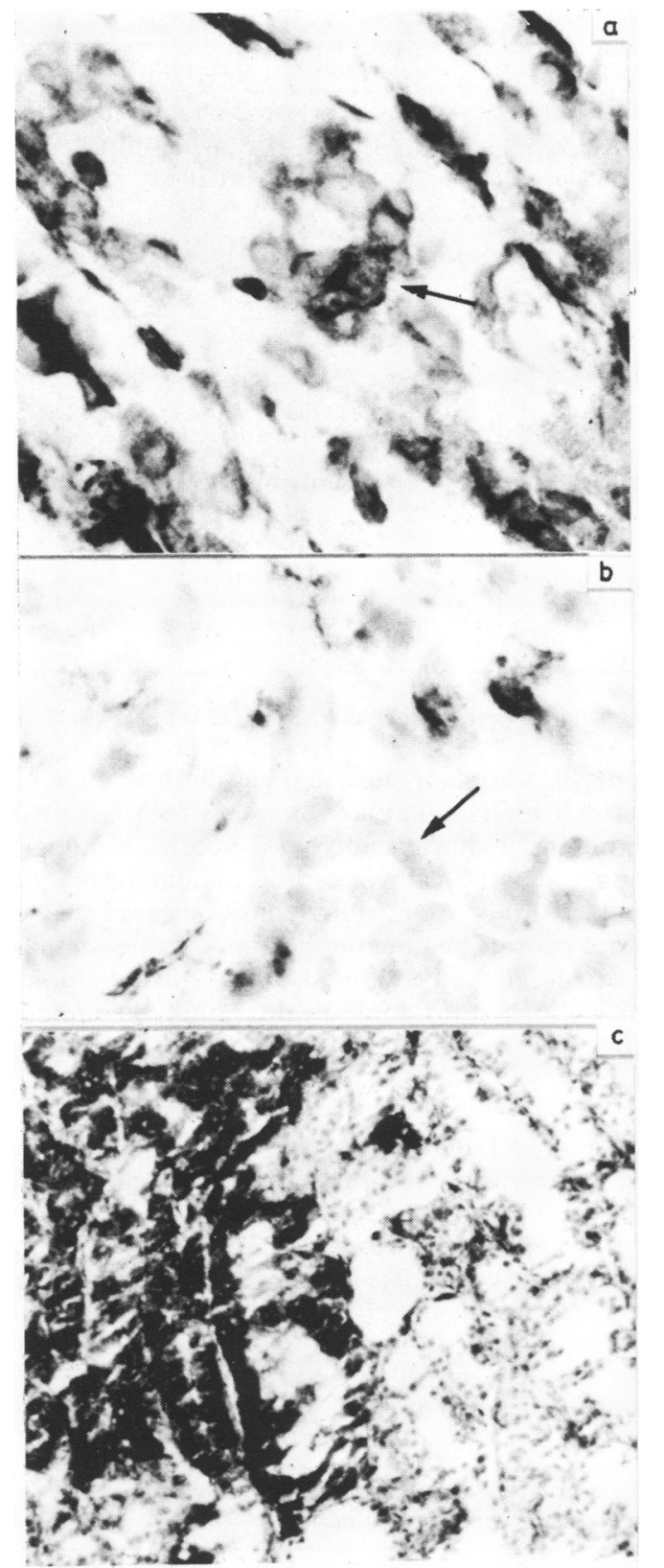

Fig. 5 Two infiltrating ductal carcinomas of breast showing in one case (a) HLA-DR positive tumour cells (arrow) and (b) in the other case, HLA-DR negative tumour cells (arrow) (both $\times 900$ ). A papillary carcinoma of the thyroid shows, however, in the same microscopic field (c) malignant epithelium which is both positive (left) and negative (right) for $H L A-D R(\times 250)$
LYMPHOMAS

Twenty-two non-Hodgkin's lymphomas were examined with the panel of antibodies, the results being given in Table 3 . These were all diffuse high grade lymphomas (shown by other investigations to be of B cell origin - see Material and methods) and all gave the same reaction pattern-that is, positive for HLA-DR and for leucocyte-associated antigen but negative for all epithelial markers.

\section{APPLICATIONS OF IMMUNOHISTOLOGY IN PROBLEM CASES}

On several occasions during this study it was possible to use the technique of monoclonal antibody immunohistology to provide additional diagnostic information when conventional histological examination yielded equivocal results. An outline of these cases is given in Table 4. Further details of three of these cases are given below.

\section{Lymphoma initially diagnosed as carcinoma}

A large axillary mass was removed from a 73-year-old man and found to consist of a collection of matted lymph nodes. The haematoxylin and eosin stained paraffin sections were diagnosed by several pathologists independently as anaplastic carcinoma (Fig. 6). However, when cryostat sections from this case were stained with the panel of monoclonal antibodies it was evident that this was a diffuse lymphoma. Further analysis using a panel of antilymphoid monoclonal antibodies (see Material and methods) showed that this tumour was negative for immunoglobulin but positive with three different anti-B cell monoclonal antibodies. In consequence management of this patient was modified and an intensive course of radiotherapy was given with good results.

\section{Carcinoma initially diagnosed as lymphoma}

An 85-year-old woman presented with subacute obstruction and was found at barium enema examination to have a large mass in the transverse colon. Fifty centimetres of colon were resected and a large nodular tumour mass involving the wall of the colon, a mass of mesenteric lymph nodes and two segments of jejunal wall were found. No tumour was visible in the bowel lumen and the mucosa of the intestine was not ulcerated at any point. Histological examination revealed an anaplastic tumour made up of large cells with open nuclei and prominent nucleoli (Fig. 7). The majority of the tumour lay deep to the intestinal muscle and was not in continuity with the colonic mucosa in any of the numerous sections studied. The sections were reviewed by a number of histopathologists and considered by the majority to represent an immunoblastic lymphoma. However, as 
Table 4 Cases illustrating the application of immunohistology

\begin{tabular}{|c|c|c|c|c|}
\hline Case No & Case history & Histology & Immunohistology & Comments \\
\hline 1 & $\begin{array}{l}\text { 73-year-old man } \\
\text { with axillary } \\
\text { lymphadenopathy: } \\
\text { no primary site } \\
\text { identified. }\end{array}$ & $\begin{array}{l}\text { Large cell } \\
\text { anaplastic tumour-- } \\
\text { consensus view: } \\
\text { carcinoma. }\end{array}$ & $\begin{aligned} \text { Positive: } & \text { HLA-DR, 2D1 } \\
& \text { (leucocyte associated). } \\
\text { Negative: } & \text { MFG (milk fat globule), } \\
& \text { SEA (cytokeratin } \\
& \text { filaments), Keratin, } \\
& \text { CEA. }\end{aligned}$ & $\begin{array}{l}\text { Immunohistology clearly revealed the } \\
\text { tumour to be a diffuse non-Hodgkin's } \\
\text { lymphoma (Fig. 6). The patient received } \\
\text { radiotherapy to good effect. }\end{array}$ \\
\hline 2 & $\begin{array}{l}\text { 85-year-old woman. } \\
\text { Extensive tumour } \\
\text { in the wall of the } \\
\text { transverse colon } \\
\text { and mesentery. }\end{array}$ & $\begin{array}{l}\text { Large cell anaplastic } \\
\text { tumour-predominant } \\
\text { opinion immunoblastic } \\
\text { lymphoma. }\end{array}$ & $\begin{array}{l}\text { Positive: } \text { MFG, SEA, CEA. } \\
\text { Negative: HLA-DR, 2D1, } \\
\text { Keratin. }\end{array}$ & $\begin{array}{l}\text { In contrast to case } 1 \text {, case } 2 \text { is shown to } \\
\text { be a carcinoma, presumably of primary } \\
\text { colonic origin (Fig. } 7 \text { ). }\end{array}$ \\
\hline 3 & $\begin{array}{l}\text { 62-year-old man } \\
\text { with large } \\
\text { inguinal lymph } \\
\text { node. }\end{array}$ & $\begin{array}{l}\text { Reported as anaplastic } \\
\text { tumour-type } \\
\text { unclassifiable. }\end{array}$ & $\begin{array}{l}\text { Positive: } \text { HLA-DR, 2D1. } \\
\text { Negative: HMFG, SEA, CEA, } \\
\text { Keratin. }\end{array}$ & $\begin{array}{l}\text { In both of these cases immunohistology } \\
\text { clearly identified the tumour as a diffuse }\end{array}$ \\
\hline 4 & $\begin{array}{l}\text { 58-year-old maı, } \\
\text { with large naso- } \\
\text { pharyngeal tumour. }\end{array}$ & $\begin{array}{l}\text { Two previous } \\
\text { biopsies taken. } \\
\text { Opinions divided } \\
\text { between carcinoma } \\
\text { and lymphoma. }\end{array}$ & $\begin{array}{l}\text { Positive: } \text { HLA-DR, 2D1. } \\
\text { Negative: HMFG, SEA, CEA. } \\
\text { Keratin. }\end{array}$ & $\begin{array}{l}\text { non-Hodgkin's lymphoma. These patients } \\
\text { were treated accordingly with radiotherapy. }\end{array}$ \\
\hline 5 & $\begin{array}{l}21 \text {-year-old man } \\
\text { with multiple } \\
\text { lytic tumours in the } \\
\text { bones of the skull. }\end{array}$ & $\begin{array}{l}\text { Small cell anaplastic } \\
\text { tumour, positive } \\
\text { for glycogen } \\
\text { particles. }\end{array}$ & Negative: with all antibodies. & $\begin{array}{l}\text { Both carcinoma and lymphoma were } \\
\text { clearly ruled out by immunohistology. } \\
\text { Ewing's sarcoma considered most likely } \\
\text { diagnosis (see text). }\end{array}$ \\
\hline
\end{tabular}

shown in Fig. 7 immunohistological examination clearly showed the tumour to be a carcinoma most probably of primary colonic origin in view of CEA positivity. The patient died a few days after the operation, so that this diagnosis did not alter the management of this particular case.

\section{Anaplastic tumour negative with all antibodies}

Case 5 in Table 4 illustrates a case which could not be unequivocally diagnosed using the panel of monoclonal antibodies although their use was, by exclusion, of some practical help. This patient was a 21-year-old man who presented initially with a tumour in one of his ribs. The histological diagnosis was of a diffuse non-Hodgkin's lymphoma and treatment with radiotherapy and chemotherapy was instituted. However, within a few months the patient returned with numerous lytic deposits in the bones of his skull. Biopsies of this recurrent tumour revealed a small cell anaplastic tumour, in which the cells were rich in glycogen, but could not be further defined.

Immunohistology was negative for all seven antibodies making a lymphoma or carcinoma unlikely (Fig. 8). Although all the evidence now points to a Ewing's sarcoma this case highlights the fact that our current panel of antibodies is of limited value (because of the absence of positive reactions) in the analysis of sarcomatous tumours.

\section{Discussion}

This study has compared the reactivity patterns of a number of monoclonal antibodies with normal and neoplastic human tissues, and has illustrated the way in which human tumour samples which cannot be diagnosed with certainty on purely histological grounds may be categorised by immunohistological labelling using monoclonal antibodies (Table 5\& Before considering the implications of these finding for the practice of routine diagnostic histopatholog the reaction pattern for individual antibodies detailed above may be reviewed in the context of previous studies.

\section{HLA-DR (ANTIBODY CR3/43)}

This antigen is the human homologue of the Ia-antigen of other species. Ia-antigen has been the subject of extensive study by transplantation immunologists because of its role in graft rejection. ${ }^{9}$ It is present not only on cells directly involved in the immune response - for example, $B$ cells, activated $T$ cells, Langerhans cells, dendritic cells - but also on a variety of epithelial cells. Expression by individual

Table 5 Summary of the major reaction patterns of the panel of monoclonal antibodies

\begin{tabular}{lll}
\hline Antigen & Carcinoma & Lymphoma \\
\hline HLA-DR & $-1+$ & + \\
Leucocyte-associated antigen & - & + \\
Milk fat globule antigen & $+1-$ & - \\
Simple epithelium cytokeratin filaments & $+1-$ & - \\
Carcinoembryonic antigen & $+1-$ & - \\
Keratin & $-/+$ & -
\end{tabular}

Symbols as in Table 2.

Although there are indications that squamous and adenocarcinomas can be distinguished (see text) insufficient cases have as yet been studied to make firm pronouncements. 


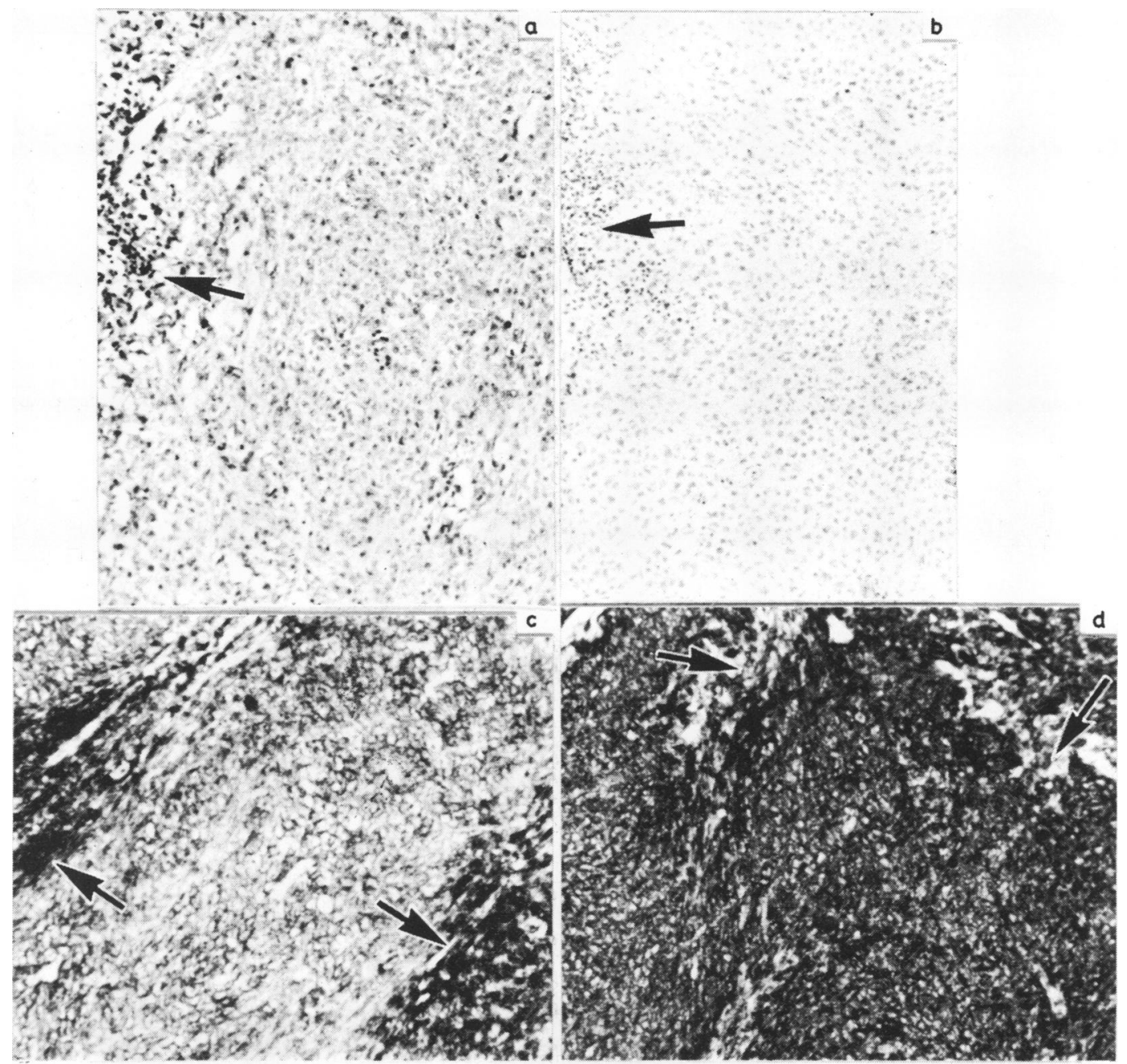

Fig. 6 Illustrations from case 1, Table 4 ("lymphoma initially diagnosed as carcinoma"). (a) A haematoxylin and eosin stained paraffin section shows sheets of tumour cells interspersed with islands of small cells. Staining of a cryostat section for intermediate filaments (b) is negative but the tumour cells are positive for leucocyte-associated antigen (c) and for $H L A-D R(d)$. The arrows indicate the islands of small cells which are strongly positive for leucocyte-associated antigen (c) and negative for $H L A-D R(d)$. Additional studies (data not shown here) indicated that these islands are mainly composed of $T$ lymphocytes (all $\times 400)$

epithelial cells appears to be a variable feature however, influenced by such extrinsic factors as hormonal changes associated with pregnancy and lactation, ${ }^{10}$ or by the development of graft versus host disease. ${ }^{112}$ This variability may account for the recently reported uneven cell-to-cell variation in Iaantigen expression in guinea pig urinary tract epithelium. ${ }^{13}$ Previous immunohistological studies of HLA-DR antigens on human mammary, bronchial and intestinal epithelia suggests that its expression shows a similar variability to that observed for Iaantigen in animals. ${ }^{14}$ This feature of human epithelial HLA-DR expression was confirmed in the present study. Furthermore, in keeping with the ability of some human epithelial cells to express HLA-DR, a proportion of carcinoma samples were also found to express this antigen. This confirms previous reports of HLA-DR expression by human carcinomas. ${ }^{15}$ An important technical point is that in this and a previous study $^{15}$ carcinoma cells were examined in tissue 


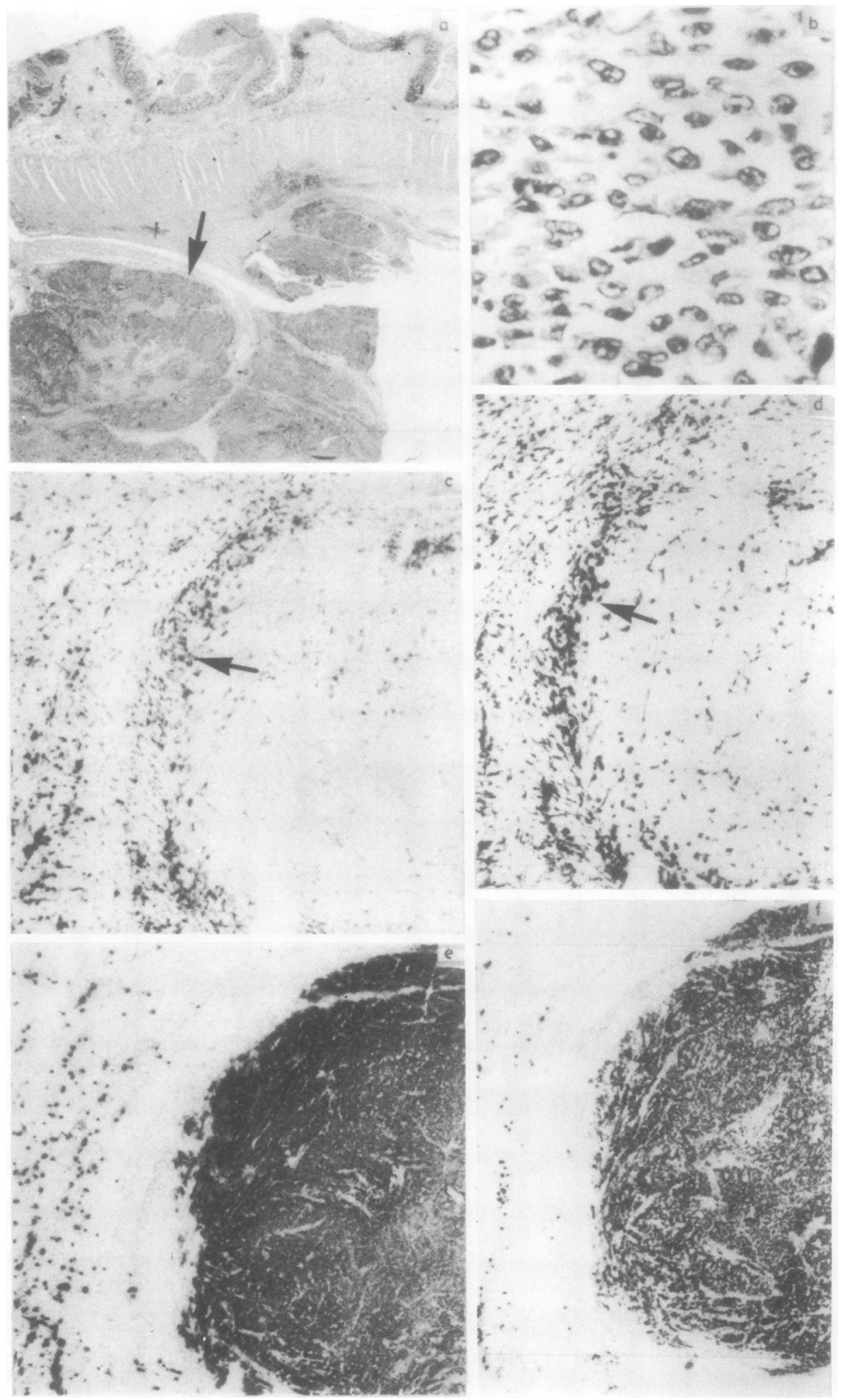

Fig. 7 Illustrations from case 2, Table 4 ("carcinoma initially diagnosed as lymphoma"). A haematoxylin and eosin stained paraffin section (a) shows a tumourlying beneath the mucosa $(\times 60)$. At higher magnification (b) the primitive nuclear morphology is visible $(\times 900)$. Staining of cryostat sections revealed that the tumour was negative for leucocyte-associated antigen (c) and HLA-DR (d), but strongly positive for $C E A(e)$ and for intermediate filaments $(f)$. Note that reactive host cells (arrowed) infiltrating the tumour are positively stained for leucocyte-associated antigen (c) and for $H L A-D R(d)(\times 450)$ 


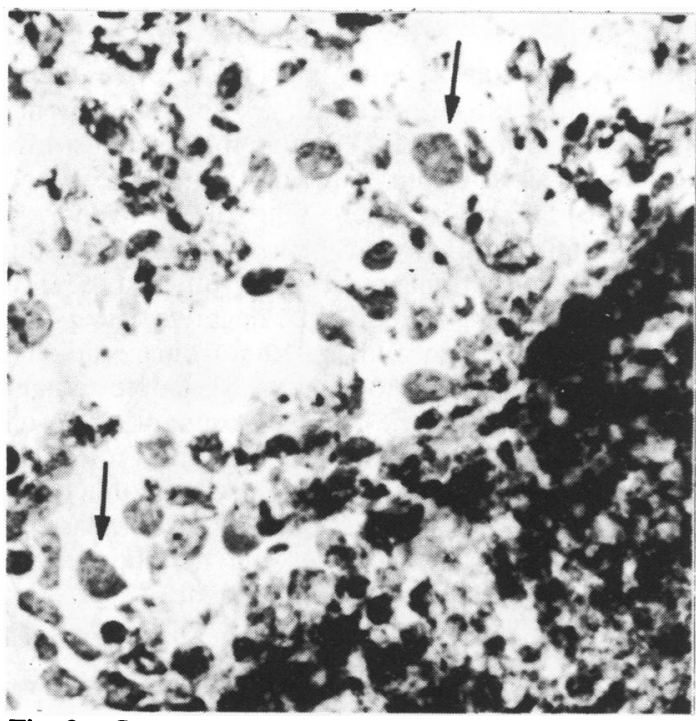

Fig. 8 Cryostat sections from case 5, Table 4, stained for leucocyte-associated antigen. Anaplastic negatively stained tumour cells (arrow) are seen contrasting with strongly positive lymphocytes (bottom right) $(\times 900)$

sections, with the consequence that intracytoplasmic HLA-DR antigen would be detectable as well as surface HLA-DR. This is relevant to a study ${ }^{16}$ in which HLA-DR positivity was found in only $5 \%$ of carcinoma samples when analysing neoplastic cells in suspension (a technique which only allows the detection of cell surface antigens).

The variability in HLA-DR antigen expression characteristic of normal epithelial cells was also evident when studying carcinoma samples. It remains to be determined whether HLA-DR expression by human carcinoma is of any prognostic significance.

In contrast to the expression of HLA-DR by a proportion of carcinoma samples, the antigen was detectable in all of the diffuse B cell lymphoid neoplasms studied, in keeping with numerous previous studies of lymphoma. ${ }^{16-20}$

The present study has also confirmed the ubiquitous distribution in human tissue of the distinctive, irregularly shaped "dendritic" cells which stain strongly for HLA-DR. These cells have previously been most extensively studied in animals ${ }^{78}$ where they appear to have an as yet incompletely defined stimulatory role in certain immunological reactions-for example, the mixed leucocyte reaction. $^{7}$

In summary therefore negative staining for HLA-DR on a tumour sample argues against the growth being of lymphoid origin - for example, case 2 in Table 4. However, positive staining for this antigen is less informative since it may occur in both lymphoma and carcinoma samples.

\section{MILK FAT GLOBULE ANTIGENS (ANTIBODIES}

MFG-1 AND MFG-2)

SPECIFICITY OF REACTION OF MFG-1 AND 2

These antibodies were raised against a delipidated preparation of the human milk fat globule and react with a component of the membrane which is not destroyed in formalin-fixed paraffin-embedded tissue. ${ }^{4}$ When tested by immunoperoxidase staining on sections of such tissues, the antibodies were found to react with lactating breast, primary breast carinomas and only to a very limited degree with resting normal breast. ${ }^{4}$ They did, however, show positive reactions with epithelial cells in some other exocrine glands or ducts and with renal tubules; the number and kind of tumours other than breast which were examined originally was limited, but ovary, lung and uterus appeared positive.

In the present investigation testing of acetone-fixed cryostat sections using the PAP technique revealed a somewhat wider range of tissues stained by these two antibodies. All normal glandular epithelia appeared to be positive, with the exception of prostate and liver. As might be expected from the spectrum of reaction with normal tissues, the MFG antibodies showed some positive reaction with most adenocarcinomas using the techniques for preparation and staining of tissue described here.

The reactions of MFG-1 and 2 resemble those reported by Sloane and Ormerod ${ }^{21}$ using a polyclonal antiserum raised by injecting rabbits with a delipidated preparation of the human milk fat globule. The major component recognised by this antiserum has been termed "epithelial membrane antigen", and it is likely that the monoclonal antibodies MFG-1 and 2 are recognising different epitopes on this or a similar component.

In summary the anti-MFG antibodies proved of value in confirming the epithelial origin of neoplasms, since lymphoid tissues consistently failed to react with these antibodies.

CYTOKERATIN FILAMENTS (SEA-ANTIBODY LE61) Cytokeratins are the group of proteins which make up the intermediate filaments of epithelial cells, and which are specific to these cells; thus they provide useful markers for epithelial cells in vitro and in vivo, as has already been demonstrated using polyclonal antisera. ${ }^{2223}$ This group of proteins is very heterogeneous and there are indications that subgroups, when suitably identified, will be useful in categorising tissues with greater specificity. ${ }^{2425}$ LE61 is a monoclonal antibody which was raised against cytokeratins of a marsupial kidney cell line ${ }^{5}$ and it 
shows broad species cross-reactivity to a limited range of cytokeratin filaments. Its determinant has been referred to as a simple epithelium antigen (SEA) ${ }^{525}$ since it is restricted to the simple types of epithelia which do not form complex stratified squamous tissues and which will not normally become keratinised. The spectrum of reaction with human epithelial tissues and tumours is similar to, but wider than, that of the MFG antibodies.

The epidermal squamous carcinoma investigated here was negative with LE61 and the squamous lung carcinoma was positive; these two reactions are unchanged from those of the normal tissues from which the tumours were derived. It should be noted that neoplastic transformation, which generally results in a loss of some differentiated functions, can induce expression of cytokeratin SEA in normally negative stratified squamous epithelial cells (Lane, Leigh and Rupniak, manuscript in preparation). One should bear in mind that such phenotypic alteration could affect other monoclonal antibody determinants as well.

In summary the SEA cytokeratin filament antibody LE61 was of value in detecting carcinoma cells and distinguishing them from lymphoid neoplasms (which consistently failed to react with the cytokeratin antibody). A negative reaction does not however rule out an epithelial origin of a tumour, since keratinocyte-derived carcinomas may be either negative or positive.

\section{KERATIN (ANTIBODY K92)}

Keratin is an insoluble complex of intracellular proteins, consisting predominantly of cross-linked filament proteins (cytokeratin-related prekeratins) ${ }^{26}$, matrix proteins-for example, filaggrins ${ }^{26}$ and a highly cross-linked cell envelope protein (involucrin $^{27}$ ). Keratin is produced by the distal layers of keratinocytes in stratified squamous epithelium of epidermis and its orifices and abnormally elsewhere-for example, some tumours. Of these three components, some but not all of the filamentous constituents appear to be common to all epithelia; filaggrin-like filament-associated proteins may also be found in other epithelia, but involucrin has so far only been found in keratinising epithelia, where it occurs in all but the basal layers of the tissue.

Conventional antisera raised against fully differentiated insoluble stratum corneum keratin ${ }^{28-30}$ usually contain a predominance of antifilament antibodies, and are generally widely cross-reactive with both squamous and glandular epithelia. Lymphoid tissue however has always been consistently negative. Carcinomas give reaction patterns in keeping with these results in that squamous neoplasms are strongly reactive whereas adenocarcinomas react weakly or not at all. Lymphoid neoplasms are always negative when stained with anti-prekeratin. ${ }^{31-33}$ The monoclonal antikeratin antibody (K92) used in the present study, which was raised against hair, has a more restricted pattern of reactivity than that of the reported conventional antikeratin sera. Non-keratinising squamous epithelium, and also other types of glandular epithelia, tended to be negative, except for a minority of benign and malignant duct epithelial cells in the breast. In contrast to the SEA determinant recognised by LE61, the K92 determinant may well be indicative of terminal keratinising differentiation.

In summary a positive reaction with monoclonal antikeratin excludes the possibility that a neoplasm is of lymphoid origin; it defines the neoplasm as a carcinoma, and provides evidence for its differentiated, keratinising nature.

\section{LEUCOCYTE-ASSOCIATED ANTIGEN}

(ANTIBODY 2D 1)

This antibody (2D1) reacts with a molecule which is probably the human homologue of the L-C antigen of the rat. Previous studies of human tissues have demonstrated that this molecule is confined to cells of bone marrow and lymphoid origin. ${ }^{2}$ The value of this antibody as a means of differentiating between lymphoma and non-lymphoid neoplasms was emphasised in a previous study of 34 malignant tissue biopsies reported by Pizzolo et al. ${ }^{19}$ Twenty of their cases were lymphomas, all of which gave positive reactions, while 12 epithelial neoplasms and sarcomas were negative. The remaining two cases were both 2D1-negative; one was a probable carcinoma, the other unclassifiable.

The results reported above are in full agreement with this earlier data, in that all $22 \mathrm{~B}$ cell lymphomas studied were positive, whilst epithelial tissues were consistently negative. The practical value of this antibody in identifying lymphoid neoplasms was evident in cases 1,3 and 4 (Table 4).

In summary $2 \mathrm{D} 1$ is a valuable antibody since it strongly labels all lymphoid neoplasms and fails to stain any neoplasms of non-leucocyte origin.

CARCINOEMBRYONIC ANTIGEN (CEA-ANTIBODY 11.285.14)

This antigen has been investigated in the past by a number of authors using paraffin-enbedded samples of normal and malignant tissue and polyclonal antiCEA antiserum (reviewed by Goldberg, Sharkey and Primus).$^{34}$ In these previous studies CEA was found principally in gastrointestinal epithelium (both benign and malignant) and also in squamous carcinomas of lung and uterine cervix. Neoplasms of breast, prostate, kidney, larynx, lymphoreticular 
system, soft tissue and brain on the other hand were negative.

Our present findings using a monoclonal anti-CEA antibody are in keeping with these earlier results in that benign and malignant gastric and colonic epithelium was positive. Non-keratinising squamous epithelium in the tonsil was also positive though skin and the squamous cell carcinoma of lung gave a negative reaction. Goldenberg $e ~^{a} l^{34}$ noted that only $30 \%$ of this type of carcinoma gave positive reactions when stained in paraffin sections. More extensive testing of the monoclonal anti-CEA might well reveal a minority of positive squamous cell carcinomas.

More recently Goldenberg et $\mathbf{l}^{35}$ have extended their studies by the use of fresh ethanol-fixed cryostat sections. In this type of material a larger numbur of tissues showed CEA positivity, a finding which is in keeping with the results reported in the present paper. However they reported less than $2 \%$ of breast carcinomas to be positive whereas six of our 11 ductal carcinomas were positive. This probably reflects differences in individual antibodies as much as technique since other authors, using different polyclonal anti-CEA antibodies, have reported much higher positive detection rates in breast carcinomas. ${ }^{36} 37$

In summary CEA was a useful ancillary indicator of the epithelial nature of a neoplasm. Although a negative reaction did not exclude the possibility of carcinoma, a positive reaction clearly indicated that a neoplasm was not of lymphoid origin.

\section{General conclusions}

Numerous immunohistological studies aimed at identifying and distinguishing different types of human malignancy have been reported in the past. However, the majority of these have been based upon the use of a single polyclonal antiserum. The limitation of using a single antiserum is that, as pointed out by Sloane and Ormerod," "negative results are, of course, unhelpful". The reason for this is that whereas positive labelling indicates that a tumour arises from a cell type which normally carries the particular antigen, a negative reaction is open to a number of different interpretations. Apart from the obvious one-that is, that the tumour derives from an antigen-negative cell population-it is also possible that the negative reaction is due to loss of the antigen as a result of neoplastic transformation, or to technical artefact-for example, denaturation of the antigen during tissue processing.

In the present study we have attempted to overcome this problem by using a panel of seven monoclonal antibodies directed against six different antigens. In consequence tumours which were negative with one monoclonal antibody were almost always positive with at least one other reagent, thus removing the uncertainties inherent in a negative reaction (Table 5). The one exception, case 5 (Table 4 ), illustrates the current limitation of our panel of antibodies rather than any inherent weakness in this approach.

In selecting antibodies for the panel we attempted to include both those which are totally (ie antileucocyte-associated antigen), or partially (ie anti-HLA-DR) specific for lymphoid neoplasms, together with others which react to varying degrees with epithelial cells (ie anti-MFG, anticytokeratin (SEA), antikeratin and anti-CEA), but not with lymphoid neoplasms. The antiepithelial group of antibodies had further discriminatory power in that they appeared to allow the two major types of human carcinoma (squamous and adenocarcinoma) to be differentiated (ie antikeratin preferentially labels the former tumour type, whereas anti-MFG and antiintermediate filament antibodies react mainly with adenocarcinomas).

The present study also represents an advance on previous immunohistological investigations of human neoplasms in that it was possible on several occasions (see Table 4) to alter an established diagnosis or to provide objective evidence when conventional histological examination gave equivocal results. All too frequently in the past immunohistological studies of tumours have been of little or no clinical relevance, serving only to demonstrate what can be predicted from histological examination-for example, that immunoglobulin is present in plasmacytoma cells, alpha-fetoprotein in hepatoma cells, chorionic gonadotrophin in choriocarcinoma cells, etc. There are, of course, exceptions to this such as the use of thyroglobulin for tumours of thyroid origin and acid phosphatase for those of prostatic origin. The present study, however, did provide results of clinical importance and gives a preliminary indication of the way in which, as the number of available monoclonal antibodies increases, immunohistological examination of tumour samples will become increasingly essential in routine histopathological diagnosis.

A comment should be made on the fact that all the immunohistological investigations reported in this paper were based upon the use of acetone-fixed cryostat sections of fresh frozen tissue. At first sight this may appear to impose a considerable restriction upon the application of monoclonal antibody immunohistology in routine histopathology laboratories. Not only does tissue have to be received and "cut up" within a short time of surgical removal, but there is also the inconvenience of freezing multiple routine samples and of being unable to perform retrospective studies on routine paraffin 
blocks. The question therefore arises of whether it might be possible to perform the labelling reactions described above on paraffin-embedded tissue, particularly in view of the fact that three of the antigens analysed in this study (keratin, CEA and the epithelial membrane antigen) have been studied in the past in paraffin-embedded tissue.

A full discussion of this topic is beyond the scope of this paper. However, in the authors' opinion the advantages of using cryostat sections greatly outweighs their disadvantages.

Firstly three of the antigens investigated (leucocyte-associated antigen, HLA-DR and cytokeratin filaments) lose their reactivity following formalin-fixation and paraffin-embedding. Many other antigens which can be recognised with recently developed monoclonal antibodies also suffer in this way-for example, antigens specific for $T$ cells and their sub-sets, surface membrane Ig etc. Furthermore, many of the antigens which will be detected in the future as new monoclonal antibodies become available will undoubtedly also be affected. Hence the great potential value of monoclonal antibody immunohistology as an adjunct to conventional histological examination will be greatly reduced if it is only applied to paraffin-embedded material.

Secondly it should be emphasised that the procedure for handling tissue sections (involving thorough drying after cutting and adequate fixation) leads to good preservation of tissue morphology. If immunoperoxidase-stained cryostat sections are examined in parallel with the routine haematoxylin and eosin stained paraffin section from a tumour there is no difficulty in discerning whether or not it is the malignant cell population which is labelled for an individual antigen.

In conclusion we suggest that the introduction of immunoperoxidase staining of cryostat sections using panels of selected monoclonal antibodies is an important improvement in diagnostic histopathology. The study reported in this paper provides only a very preliminary indication of the potential value of this approach, which is likely to become increasingly important as more monoclonal antibodies against tissue constituents become available.

We are grateful to R-E Woolston for technical assistance and to Diane Smith for typing the manuscript. This work was supported by the Leukaemia Research Fund.

\section{References}

' Naiem M, Gerdes J, Abdulaziz Z, Nash JRG, Stein H, Mason DY Production of monoclonal antibodies for the immuno- histological analysis of human lymphoma. In: Knapp W, et al, eds. Leukaemia markers. New York: Academic Press, 1981:117-25.

${ }^{2}$ Beverley P. Production and use of monoclonal antibodies in transplant immunology. Proceedings $\mathrm{XI}^{\text {th }}$ International Course on Transplant and Clinical Immunology. Amsterdam: Excerpta Medica, 1981:87-94.

${ }^{3}$ Taylor-Papadimitriou J, Peterson JA, Arklie J, Burchell J, Ceriani RL, Bodmer WF. Monoclonal antibodies to epithelium-specific components of the human milk fat globule membrane: Production and reaction with cells in culture. Int $J$ Cancer 1981;28:17-21.

+ Arklie J, Taylor-Papadimitriou J, Bodmer W, Egan M, Millis R. Differentiation antigens expressed by epithelial cells in the lactating breast are also detectable in breast cancers. Int $J$ Cancer 1981:28:23-9.

${ }^{5}$ Lane EB. Monoclonal antibodies provide specific intramolecular markers for the study of epithelial tonofilament organisation. J Cell Biol 1982;92:180-9.

${ }^{6}$ Mason DY, Cordell JL, Abdulaziz Z, Naiem M, Bordenave G. Preparation of PAP complexes for immunohistological labelling of monoclonal antibodies. J Histochem Cytochem (in press)

' Steinman RM. Dendritic cells. Transplantation 1981;31:151-5.

${ }^{8}$ Hart DNJ, Fabre JW. Demonstration and characterization of Ia-positive dendritic cells in the connective tissues of rat heart interstitial and other tissues, but not brain. J Exp Med $1981 ; 154: 347-61$.

${ }^{9} \mathrm{Katz} \mathrm{D}$, Benaceraff $\mathrm{B}$, eds. The role of the products of the histocompatibility gene complex in immune responses. London: Academic Press, 1976.

${ }^{10}$ Klareskog L, Forsum U, Peterson PA. Hormonal regulation of the expression of Ia-antigens on mammary gland epithelium. Eur $J$ Immunol 1980;10:958-63.

" Lampert IA, Suitters AJ, Chisholm PM. Expression of Ia-antig on epidermal keratinocytes in graft-versus-host disease. Nature. 1981;293:149-50.

${ }^{12}$ Mason DW, Dallman M, Barclay AN. Graft-versus-host disease induces expression of Ia-antigen in rat epidermal cells and gut epithelium. Nature 1981;293:150-1.

${ }^{13}$ Forsum U, Klareskog L, Peterson PA. Distribution of Ia-antigen like molecules on non-lymphoid tissues. Scand J Immunol 1979;9:343-9.

${ }^{14}$ Natali PG, Martino CD, Quarante V, et al. Expression of Ia-like antigens in normal human non-lymphoid tissues. Transplantation 1981;31:75-8.

is Natali PG, Martino CD, Quarante V, Bigotti A, Pellegrino MA, Ferrone $S$. Changes in Ia-like antigen expression of malignant human cells. Immunogenetics 1981;12:409-13.

${ }^{16}$ Kadin ME. Ia-like (HLA-DR). Antigens in the diagnosis of lymphoma and undifferentiated tumours. Arch Pathol Lab Med 1980;104:503-8.

${ }^{17}$ Halper JP, Knowles DM II, Wang CY. Ia-antigen expression by human malignant lymphomas: Correlation with conventional lymphoid markers. Blood 1980;55:373-82.

is Janossy G, Thomas JA, Pizzolo G, et al. Immunohistological diagnosis of lymphoproliferative diseases by selected combinations of antisera and monoclonal antibodies. $\mathrm{Br} J$ Cancer 1980;42:224-42.

${ }^{19}$ Pizzolo G, Sloane J, Beverley P, et al. Differential diagnosis of malignant lymphoma and non-lymphoid tumours using monclonal anti-leucocyte antibody. Cancer 1980;46:2640-7.

${ }^{20}$ Warnke R, Miller R, Grogan T, Pederson M, Dilley J, Levy R. Immunologic phenotype in 30 patients with diffuse large-cell lymphoma. N Engl J Med 1980;303:293-300.

${ }^{21}$ Sloane JP, Ormerod MG. Distribution of epithelial membrane antigen in normal and neoplastic tissues and its value in diagnostic tumour pathology. Cancer 1981;47:1786-95.

${ }^{22}$ Sun T-T, Shih C, Green H. Keratin cytoskeletons in epithelial cells of internal organs. Proc Natl Acad Sci USA 1979;76:2813-7. 
${ }^{23}$ Franke WW, Appelhans B, Schmid E, Freudenstein C, Osborn M, Weber K. Identification and characterization of epithelial cells in mammalian tissues by immunofluorescence microscopy using antibodies to prekeratin. Differentiation 1979;15:7-25.

${ }^{24}$ Franke WW, Denk H, Kalt R, Schmid E. Biochemical and immunological identification of cytokeratin proteins present in hepatocytes or mammalian liver tissue. Expl Cell Res 1981;131:299-318.

${ }^{25}$ Lane EB, Klymkowsky MW. Epithelial tonofilaments: investigating their form and function using monoclonal antibodies. Cold Spring Harbor Symp Quant Biol 1982;46: chapter 36.

${ }^{26}$ Matoltsy AG. Desmosomes, filaments and keratohyaline granules: their role in the stabilization and keratinization of the epidermis. J Invest Dermatol 1975;65:127-42.

${ }^{27}$ Steihert PM, Cantieri JS, Teller DC, Lonsdale-Eccles JD, Dale BA. Characterization of a class of cationic proteins that specifically interact with intermediate filaments. Proc Natl Acad Sci USA 1981;76:4097-101.

${ }^{28}$ Banks-Schlegel $S$, Green $H$. Involucrin synthesis and tissue assembly by keratinocytes in natural and cultured human epithelia. J Cell Biol 1981;90:732-7.

${ }^{29}$ Sun TT, Green H. Keratin filaments of cultured human epidermal cells: formation of intermolecular disulfide bonds during terminal differentiation. J Biol Chem 1978;253:2053-60.

${ }^{30}$ Franke WW, Weber K, Osborn M, Schmid E, Freudenstein C. Antibody to prekeratin. Decoration of tonofilament-like assays in various cells of epitnelial character. Exp Cell Res 1978;116:429-45.
${ }^{31}$ Schlegel R, Banks-Schlegel S, McLeod JA, Pinkus GS. Immunoperoxidase localization of keratin in human neoplasms. Am J Pathol 1980;101:41-8.

${ }^{32}$ Battifora H, Sun TT, Bahu RM, Rao S. The use of antikeratin antiserum as a diagnostic tool: thymoma versus lymphoma. Hum Pathol 1980;11:635-7.

${ }^{33}$ Loning T, Staquet MJ, Thivolet J, Seifert G. Keratin polypeptides distribution in normal and diseased human epidermis and oral mucosa. Virchows Arch [Pathol Anat] 1980;388:273-88.

${ }^{34}$ Goldenberg DM, Sharkey RM, Primus FJ. Carcino-embryonic antigen in histopathology: immunoperoxidase staining of conventional tissue sections. J Natl Cancer Inst 1976;57:11-22.

${ }^{35}$ Goldenberg DM, Primns FJ, De Land F. Tumour detection and localisation with purified antibodies to carcino-embryonic antigen. In: Herberman RB, McIntire KR, eds. Immunodiagnosis of cancer. New York and Basel: Marcel Dekker, 1979:265-304.

${ }^{36}$ Heyderman E, Munro Neville A. A shorter immunoperoxidase technique for the demonstration of carcinoembryonic antigen and other cell products. J Clin Pathol 1977;30:138-40.

${ }^{37}$ Walker RA. Demonstration of carcinoembryonic antigen in human breast carcinomas by the immunoperoxidase technique. J Clin Pathol 1980;33:356-60.

Requests for reprints to: Dr KC Gatter, Department of Pathology, John Radcliffe Hospital, Headington, Oxford OX3 9DU, England. 